\title{
UJI KETAHANAN NILAM TERHADAP Synchytrium pogostemonis PENYEBAB PENYAKIT BUDOK DAN POTENSI PENGENDALIANNYA DENGAN PESTISIDA NABATI
}

\author{
Resistance of Patchouli to Synchytrium pogostemonis Causing of Budok Disease and Potential Control \\ with Natural Pesticides
}

Tri Yuliyanti ${ }^{1}{ }^{1}$ ), Sri Yuni Hartati ${ }^{2)}$, Reni Indrayanti ${ }^{1{ }^{1 *}}$

1) Progrm Studi Biologi FMIPA Universitas Negeri Jakarta Jl. Pemuda No. 10 Rawamangun, Jakarta Timur. Indonesia.

2) Balai Penelitian Tanaman Rempah dan Obat (BALITRO). Jln. Tentara Pelajar Bogor Indoensia

*Corresponding Email: rindrayanti@unj.ac.id

\begin{abstract}
ABSTRAK
Nilam (Pogostemon cablin Benth.) merupakan tanaman semak penghasil minyak atsiri yang memiliki nilai ekonomi yang tinggi. Budidaya tanaman nilam memiliki kendala yaitu adanya serangan kapang Synchytrium pogostemonis penyebab penyakit budok. Tujuan dari penelitian ini adalah untuk mengetahui ketahanan 3 varietas nilam terhadap penyakit budok, dan mengetahui efektivitas dari formula tunggal dan campuran minyak mimba dan seraiwangi terhadap kejadian penyakit budok dan pengaruhnya pada pertumbuhan tanaman. Penelitian ini terdiri dari dua percobaan: 1) Efektivitas metode infeksi dan uji ketahanan tiga varietas nilam terhadap penyakit budok di rumah kaca, dan 2) Uji efektivitas minyak atsiri formula tunggal maupun campuran mimba dan seraiwangi sebagai pestisida nabati terhadap penyakit budok. Hasil percobaan efektivitas metode infeksi menujukkan bahwa metode perendaman akar tanaman dalam inokulum budok selama satu jam lebih efektif menginfeksi penyakit budok dibandingkan dengan metode penyiraman ke media tanam. Hasil uji ketahanan nilam varietas Sidikalang, Patchoulina 1 dan Patchoulina 2 menunjukkan bahwa varietas Patchoulina 1 lebih rentan terhadap penyakit budok karena menimbulkan keterjadian penyakit $(\mathrm{KeP})$ dan keparahan penyakit (KP) hingga $20 \%$, dengan karekter pertumbuhan tinggi tanaman yang lebih rendah dibandingkan varietas lain yang diuji. Sedangkan diantara minyak atsiri yang diujikan, formula minyak atsiri campuran (mimba dan seraiwangi) konsentrasi $0.5 \%$ lebih efektif dalam mengurangi penyakit budok, namun efektivitasnya masih lebih rendah dibandingkan dengan perlakuan fungisida benomil $0,3 \%$ dan bubur bordo $0,1 \%$. Aplikasi formula minyak atsiri secara signifikan tidak berpengaruh negatif terhadap pertumbuhan nilam, sehingga formula campuran (mimba dan seraiwangi) $0,5 \%$ dapat digunakan untuk mengontrol penyakit budok pada tanaman nilam.
\end{abstract}

Kata kunci : Minyak atsiri, Nilam, Mimba, Penyakit Budok, Seraiwangi.

\section{PENDAHULUAN}

Nilam (Pogestemon cablin Benth.) merupakan salah satu tanaman penghasil minyak atsiri yang menyumbang devisa Negara cukup besar. Minyak nilam tersebut mempunyai banyak manfaat sehingga sering digunakan dalam 
industri kosmetik, parfum, antiseptik, dan lain sebagainya. Produksi minyak nilam di Indonesia masih terbatas dan belum optimal, dan banyak factor yang mempengaruhinya diantaranya kurangnya pengetahuan petani mengenai cara budidayanya tanaman nilam dan pengolahan pasca panen, serta adanya fluktuasi harga minyak yang dipengaruhi oleh produksi kadar dan kualitas dari minyak nilam (Wahyuno, 2010).

Pengembangan budidaya tanaman nilam mengalami banyak hambatan ketika di lapangan. Tanaman nilam selama pertumbuhannya tidak terlepas dari Organisme Pengganggu Tanaman (OPT) terutama di daerah beriklim tropis seperti Indonesia karena kondisi ini akan sangat mendukung perkembangan OPT. Penyakit yang sering menyerang tanaman nilam diantaranya adalah penyakit layu bakteri, penyakit budok, serta penyakit yang disebabkan oleh nematoda dan virus (Wahyuno et al., 2011). Gejala penyakit budok seperti daun menjadi berwarna ungu kemerahan dan disertai terbentuknya kutil (scabies) pada permukaan bagian tanaman yang terinfeksi. Menurut Wahyuno et al. (2007) penyakit budok disebabkan oleh jamur Synchytrium pogostemonis yang merupakan jamur tular tanah (soilborne) yang dapat menyerang daun, tangkai daun dan batang tanaman nilam terutama pucuk tanaman yang baru tumbuh. S. pogostemonis merupakan jamur parasit obligat yang hanya dapat hidup pada jaringan tanaman dan dapat bertahan didalam tanah dengan bentuk kista dalam jangka waktu yang sangat lama sampai menemukan inang baru.

Pengendalian penyakit budok dapat dilakukan dengan berbagai cara yaitu dengan menanam varietas tahan, memanfaatkan sifat antagonis agensia hayati, menggunakan pestisida nabati seperti minyak atsiri, atau fungisida kimia maupun nabati. Selain itu juga dapat dilakukan perlakuan langsung terhadap tanaman sakit misalnya dengan melakukan penyemprotan fungisida maupun pestisida. Pada saat ini varietas nilam yang tahan belum tersedia di Indonesia. Oleh karena itu perlu diuji ketahanan dari beberapa varietas nilam. Pengendalian penyakit budok dengan pestisida kimia di lapangan masih menjadi pilihan untuk mengatasi tanaman yang menunjukkan gejala sakit dalam jumlah yang cukup banyak. Namun penggunaan pestisida kimia ini memiliki dampak negatif, seperti polusi lingkungan (kontaminasi tanah, air, dan udara), resistensi hama dan patogen, serta dampak negatif lainnya.

Pestisida nabati berbasis minyak atsiri mulai banyak dikembangkan untuk mengendalikan hama dan patogen penyebab penyakit tanaman pada Eucalyptus camaldulensis dan Myrtus communis (Akin, 2010). Minyak cengkeh dapat mengendalikan pertumbuhan beberapa jenis patogen seperti bakteri Pseudomonas solanacearum (Hartati et al, 1994a; Hartati et al, 1994b) bakteri Ralstonia solanacearum asal jahe (Supriadi et al., 1999; Supriadi et al., 2008), tepung dan minyak cengkeh mengendalikan jamur Phytopthora, Rigidoporus, dan Sclerotium (Manohara et al., 1994) nematoda asal lada (Mustika dan Rahmat, 1994) dan gulma (Zanellato et al., 2009). Minyak eucalyptus juga dapat digunakan sebagai pestisida (Batish, 2008) terhadap jamur Botrytis cinerea, Fusarium oxysporum, Phythium ultimum, dan Rhizoctonia solani (Lee et. al., 2007), Colletotrichum graminicola, Phoma sorghina, Fusarium moniliforme. Hasil penelitian sebelumnya yang dilakukan dilapangan menunjukkan fungisida berbahan aktif benomil, bubur bordo, dan formula pestisida nabati berbahan aktif minyak mimba dan seraiwangi dapat menekan serangan penyakit budok pada tanaman nilam. Tujuan dari penelitian ini adalah mencari varietas nilam tahan terhadap penyakit budok dan mengetahui efektivitas dari campuran formula minyak mimba dan seraiwangi terhadap kejadian penyakit budok pada tanaman nilam. 


\section{METODOLOGI PENELITIAN}

\section{WAKTU DAN TEMPAT PENELITIAN}

Kegiatan ini dilakukan di rumah kawat Biologi Universitas Negeri Jakarta (UNJ) dan di kebun percobaan Cimanggu, Balai Tanaman Rempah dan Obat (BALITTRO) terhitung dari bulan April s.d. bulan Desember 2017.

\section{METODE PENELITIAN}

Pada penelitian ini terdapat dua macam percobaan yang terdiri dari 1) Efektivitas metode infeksi dan uji ketahanan tiga varietas nilam terhadap penyakit budok di rumah kaca; dan 2) Efektivitas minyak atsiri sebagai pestisida nabati terhadap penyakit budok pada tanaman nilam.

Peralatan yang digunkan dalam penelitian ini adalah gelas ukur 500, 2000, dan 4000 ml, kayu pengaduk, tali rafia, mistar, saringan, ember plastik, hand sprayer, polybag ukuran $12 \times 15 \mathrm{~cm}$, kantong plastik, karung plastik, cangkul, koret, selang air, timbangan, karung goni, kantong plastik, pisau.

Tanaman yang digunakan adalah benih nilam umur satu bulan hasil dari tiga varietas tanaman nilam Aceh (Sidikalang, Patchoulina 1, dan Patchoulina 2) yang disiapkan dari Unit Pengelola Benih Sumber (UPBS) BALITTRO yang tidak menunjukkan gejala penyakit budok atau penyakit lainnya. Bahan yang digunakan meliputi air, formula minyak atsiri mimba dan seraiwangi, fungisida benomil, bubur Bordo (Cu dan kapur). Bahan lainnya yang dibutuhkan yaitu pupuk organik (kotoran hewan) dan pupuk an-organik (Urea, SP-36, KCl) agar tanaman tetap subur.

Percobaan 1. Efektivitas metode infeksi dan uji ketahanan tiga varietas nilam terhadap penyakit budok di rumah kaca

Penelitian ini menggunakan metode eksperimen dengan desain rancangan acak kelompok pola faktorial. Perlakuan yang diuji sebanyak 3 varietas tanaman nilam (Sidikalang, Pathcoulina 1, dan Pathcoulina 2), dengan 2 metode infeksi dan 1 kontrol, setiap perlakuan terdiri dari 3 ulangan dan setiap ulangan terdiri atas 5 tanaman, sehingga untuk keseluruhan dibutuhkan 135 stek tanaman nilam. Percobaan ini menggunakan stek tanaman nilam varietas Sumber inokulum kapang Synchytrium pogostemonis yang merupakan parasit obligat diperoleh dengan metode yang digunakan oleh Idris dan Nasrun (2009). Cabang dan daun nilam dipotong-potong dan direndam dalam akuades steril. Perbandingan antara tanaman sakit dengan air yaitu 1:3, kemudian dikocok selama 3 jam untuk mengeluarkan zoospora yang digunakan sebagai penginfeksi. Uji ketahanan menggunakan $30 \mathrm{ml}$ suspensi inokulum budok dengan perbedaan dua metode infeksi yaitu perendaman akar dan penyiraman ke madia tanam. Pada perlakuan kontrol benih tidak diinokulasikan inokulum penyakit budok. Parameter yang diamati yaitu persentase keterjadian penyakit (KP) dan keparahan penyakit (KeP).

Percobaan 2. Efektivitas Minyak Atsiri sebagai Pestisida Nabati terhadap Penyakit Budok pada Tanaman Nilam

Metode yang digunakan dalam penelitian ini adalah eksperimen dengan menggunakan desain rancangan acak kelompok (RAK). Perlakuan yang diuji sebanyak 8 perlakuan, setiap perlakuan diulang 3 kali dan setiap ulangan ditanam 20 tanaman, sehingga keseluruhan percobaan dibutuhkan 480 tanaman nilam. Perlakuan yang terdiri dari 3 perlakuan campuran formula minyak (mimba + seraiwangi) dengan konsentrasi $0.25 \%, 0.5 \%$, dan $0.75 \%$, formula tunggal minyak mimba $0.5 \%$, formula minyak seraiwangi $0.5 \%$, fungisida benomil $3 \mathrm{gr} /$ liter, bubur bordo $10 \mathrm{gr} /$ liter, dan air sebagai kontrol sehingga total terdapat 8 perlakuan.

Tanaman nilam yang digunakan adalah varietas Sidikalang umur satu bulan. Minyak atsiri yang digunakan 
dalam bentuk kemasan formula siap pakai, yang kemudian diencerkan sesuai konsentrasi yang dibutuhkan. Benih nilam ditanam pada lahan endemik penyakit budok. Aplikasi pestisida nabati dilakukan pada saat tanaman belum menunjukkan gejala budok dan dilakukan dengan interval penyemprotan 2 minggu sekali sampai 5 kali penyemprotan. Parameter yang diamati dalam percobaan ini yaitu tinggi tanaman, jumlah cabang, bobot basah, bobot kering, dan persentase keterjadian penyakit (KP) serta keparahan penyakit (KeP).

\section{TEKNIK ANALISIS DATA}

Data penelitian berupa kuantitatif dan kualitatif (jumlah cabang) kemudian dianalisis dengan uji ANAVA 2 arah (Percobaan 1) dan ANAVA 1 arah (Percobaan 2). Apabila terdapat perbedaan dilanjutkan dengan uji lanjut Duncan's Multiple Range Test (DMRT) pada taraf 5\%.

\section{HASIL DAN PEMBAHASAN}

PERCOBAAN 1. EFEKTIVITAS METODE INFEKSI DAN UJI KETAHANAN TIGA VARIETAS NILAM TERHADAP PENYAKIT BUDOK DI RUMAH KACA.

Hasil percobaan ini diperoleh gambaran bahwa beberapa tanaman nilam dari varietas Sidikalang dan Patchoulina 2 mengalami kematian sebelum diinokulasi (Tabel 1). Tanaman nilam yang mengalami kematian tersebut tidak terdapat gejala budok. Hal ini disebabkan karena faktor lain diluar dari perlakuan yang diberikan, tidak diketahui faktor yang menjadi penyebabnya, namun diduga karena tanaman tersebut mengalami stres maupun faktor lingkungan seperti suhu dan kelembaban. Tanaman nilam merupakan tanaman yang peka terhadap kekeringan, sehingga perlu diperhatikan kelembabannya.

Tabel 1. Pengaruh Metode Infeksi Budok terhadap Persentase Keterjadian dan Keparahan Penyakit Ketiga Varietas Tanaman Nilam setelah 5 MSI

\begin{tabular}{|c|c|c|c|c|c|c|}
\hline \multirow{2}{*}{$\begin{array}{l}\text { Varietas } \\
\text { Nilam }\end{array}$} & \multirow{2}{*}{$\begin{array}{l}\text { Metode } \\
\text { Infeksi }\end{array}$} & \multirow[t]{2}{*}{ N Total } & \multicolumn{2}{|c|}{ Rerata Kematian } & \multirow{2}{*}{$\begin{array}{l}\text { Keterjadian } \\
\text { Penyakit (\%) }\end{array}$} & \multirow{2}{*}{$\begin{array}{l}\text { Keparahan- } \\
\text { Penyakit (\%) }\end{array}$} \\
\hline & & & Jumlah & $(\%)$ & & \\
\hline \multirow[t]{3}{*}{ Sidikalang } & Kontrol & 8 & 1 & 12,5 & 0,0 & 0,0 \\
\hline & Penyiraman & 9 & 1 & 22,2 & 0,0 & 0,0 \\
\hline & Perendaman & 9 & 1 & 11,1 & 0,0 & 0,0 \\
\hline \multirow[t]{3}{*}{ Patchoulina 1} & Kontrol & 9 & 3 & 33,3 & 16,7 & 8,3 \\
\hline & Penyiraman & 9 & 3 & 33,3 & 16,7 & 16,7 \\
\hline & Perendaman & 9 & 4 & 44,4 & 20,0 & 20,0 \\
\hline \multirow[t]{3}{*}{ Patchoulina 2} & Kontrol & 4 & 0 & 0,0 & 0,0 & 0,0 \\
\hline & Penyiraman & 4 & 2 & 50,0 & 0,0 & 0,0 \\
\hline & Perendaman & 4 & 1 & 25,0 & 0,0 & 0,0 \\
\hline
\end{tabular}

Hasil penelitian menunjukkan bahwa gejala telah terlihat pada 2 minggu setelah infeksi (Gambar 1. Metode infeksi dengan perendaman akar tanaman dalam inokulum budok selama satu jam lebih efektif menginfeksi penyakit budok dibandingkan dengan metode penyiraman ke media tanam. Metode infeksi perendaman akar menyebabkan patogen melakukan kontak langsung dengan tanaman. Hal ini dikarenakan pada saat pencabutan akar terjadi perlukaan, sehingga memudahkan patogen akan lebih mudah melakukan penetrasi masuk kedalam inang. Hasil percobaan tahapan ini juga menunjukkan keterjadian penyakit (KeP) akibat infeksi budok hanya terjadi pada varietas Patchoulina 1, baik yang diinokulasi dengan metode perendaman akar, penyiraman, bahkan kontrol. Munculnya 
penyakit budok pada kontrol yang tidak diinfeksi budok, disebabkan karena jarak peletakan pot yang terlalu dekat, sehingga tanaman kontrol menjadi tertular penyakit budok melalui percikan air, sedangkan varietas Sidikalang dan Patchoulina 2 tidak menunjukkan gejala budok.

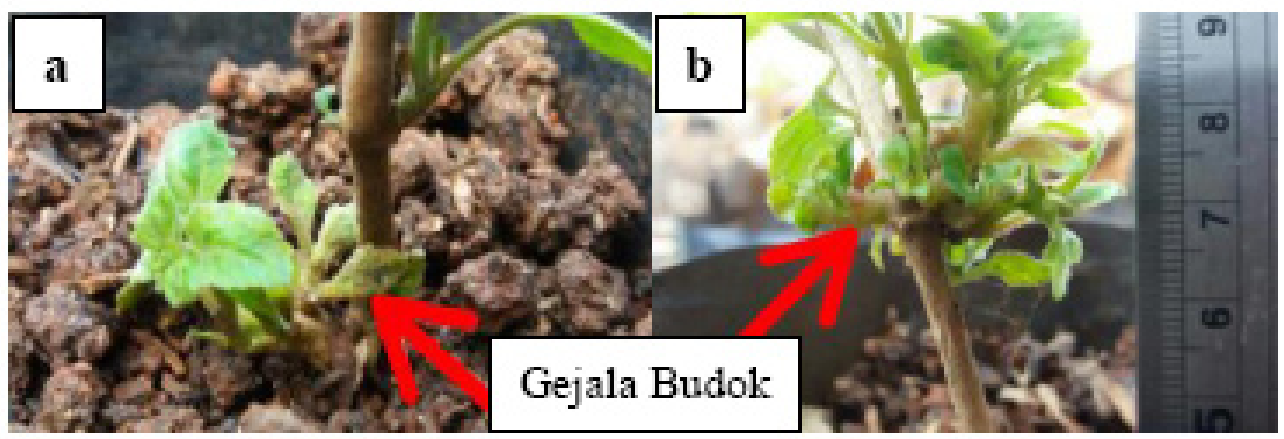

Gambar 1. Gejala awal penyakit budok pada nilam varietas Patchoulina 1 setelah 2 MSI. (a) pada tunas baru; (b) pada cabang baru

Pengukuran tinggi tanaman dilakukan untuk mengetahui pertambahan tinggi tanaman yang diinokulasi dengan Synchytrium pogostemonis setiap minggu. Pada Tabel 2 tidak terlihat adanya perbedaan yang signifikan pada tinggi tanaman pada semua perlakuan. Hal ini menunjukkan pertumbuhan tanaman nilam normal dengan atau tanpa perlakuan. Keterjadian penyakit mulai dihitung ketika tanaman nilam menunjukkan gejala penyakit budok, sedangkan keparahan penyakit dievaluasi berdasarkan skor gejala menurut Sukamto et al (2014). Keparahan penyakit dihitung setiap minggu agar mengetahui perkembangan dari gejala penyakit budok pada tiap tanaman. Hal ini dikarenakan tingkat perkembangan suatu penyakit ditentukan oleh kondisi organ atau jaringan tanaman yang relatif berbeda (Abdullahi et al. 2005).

Tabel 2. Pengaruh Metode Infeksi Budok terhadap Pertambahan Tinggi Stek Tiga Varietas Tanaman Nilam

\begin{tabular}{lllll}
\hline Varietas Nilam & Metode Infeksi & \multicolumn{4}{c}{ Rerata Tinggi Stek Nilam $(\mathrm{cm})$} & 3 MSI & MSI & MSI \\
\hline Sidikalang & Kontrol & $21,87^{\mathrm{a}}$ & $23,00^{\mathrm{ab}}$ & $22,75^{\mathrm{a}}$ \\
& Penyiraman & $21,62^{\mathrm{a}}$ & $20,75^{\mathrm{ab}}$ & $23,75^{\mathrm{a}}$ \\
\multirow{2}{*}{ Patchoulina 1 } & Perendaman & $20,25^{\mathrm{a}}$ & $19,12^{\mathrm{ab}}$ & $21,62^{\mathrm{a}}$ \\
& Kontrol & $20,67^{\mathrm{a}}$ & $22,17^{\mathrm{a}}$ & $22,83^{\mathrm{a}}$ \\
& Penyiraman & $20,00^{\mathrm{a}}$ & $23,14^{\mathrm{b}}$ & $23,14^{\mathrm{a}}$ \\
\multirow{2}{*}{ Patchoulina 2 } & Perendaman & $16,67^{\mathrm{a}}$ & $17,50^{\mathrm{ab}}$ & $18,00^{\mathrm{a}}$ \\
& Kontrol & $18,50^{\mathrm{a}}$ & $20,50^{\mathrm{ab}}$ & $22,00^{\mathrm{a}}$ \\
& Penyiraman & $19,33^{\mathrm{a}}$ & $22,67^{\mathrm{ab}}$ & $24,33^{\mathrm{a}}$ \\
& Perendaman & $17,75^{\mathrm{a}}$ & $17,25^{\mathrm{a}}$ & $19,00^{\mathrm{a}}$
\end{tabular}

Gejala budok muncul 2 minggu pasca infeksi terutama pada tanaman yang diinokulasi dengan metode perendaman akar, kemudian disusul dengan munculnya gejala yang sama pada tanaman yang diinokulasi dengan metode penyiraman media pada yaitu minggu ke 3 pasca infeksi. Pada perlakuan kontrol gejala budok muncul pada minggu berikutnya. Gejala awal budok ditandai dengan munculnya kutil berwarna hijau keunguan pada permukaan daun, ataupun pada tunas baru yang dekat dengan permukaan tanah. Tanaman yang terinfeksi penyakit budok tidak langsung menunjukkan kematian.

Varietas Sidikalang menunjukkan lebih toleran terhadap penyakit budok dan memiliki tingkat adaptasi yang tinggi dibandingkan dengan varietas Patchoulina 1 dan 2. Varietas Sidikalang juga dilaporkan toleran terhadap 
penyakit layu bakteri Ralstonia solanacearum dan toleran terhadap tiga jenis nematoda yaitu Pratylenchus brachyurus, Meloidogyne incognita, dan Radopholus similis (Mustika dan Nuryani 2006). Varietas Patchoulian 1 dan 2 merupakan hasil somaklon Sidikalang yang tahan terhadap penyakit layu bakteri, namun belum teruji terhadap penyakit budok.

Kapang Synchytrium pogostemonis memiliki struktur reproduksi berupa zoospora yang mempunyai flagela untuk motilitasnya. Zoospora tersebut dapat berenang pada lapisan air yang menempel pada partikel tanah untuk menuju ke tanaman nilam. Infeksi buatan melalui media air menyebabkan terjadinya infeksi yang lebih besar dibandingkan dengan media tanah yang basah pada tanaman nilam (Wahyuno dan Sukamto, 2010). Kapang dari bangsa Chytridiomycetes memiliki zoospora yang tidak berdinding tebal dan memiliki flagela sehingga lebih mudah melakukan kontak langsung dengan inang. Hal ini menyebabkan zoospora menjadi alternatif penyebaran infeksi saat kondisi lingkungan yang cukup lembab (Massini, 2007). Zoospora masuk kedalam tanaman inang karena adanya gula dan asam amino yang dikeluarkan oleh akar tanaman. Spora aktif (zoospora) akan berenang menghampiri inang. Spora akan melekat pada permukaan inang karena terjadi adhesi melalui pelepasan enzim kutinase oleh spora. Pelekatan spora ini memungkinkan adanya transmisi sinyal untuk perkecambahan spora dan pembentukan struktur infeksi. (Agrios 2005).

Tabel 3. Pengaruh Perlakuan Minyak Atsiri dan Fungisida Kimia terhadap Synchytrium pogostemonis pada Pertumbuhan Tanaman Nilam yang ditanam pada Lahan Endemik Budok pada Umur 6 Bulan

\begin{tabular}{lllll}
\hline Perlakuan & $\begin{array}{l}\text { Pertambahan } \\
\text { Cabang } \\
(\text { Rerata } \pm \text { SE })\end{array}$ & $\begin{array}{l}\text { Pertambahan } \\
\text { Tinggi }(\mathrm{cm}) \\
(\text { Rerata } \pm \text { SE })\end{array}$ & $\begin{array}{l}\text { Bobot Basah }(\mathrm{kg}) \\
(\text { Rerata } \pm \text { SE) }\end{array}$ & $\begin{array}{l}\text { Bobot Kering }(\mathrm{kg}) \\
(\text { Rerata } \pm \text { SE) }\end{array}$ \\
\hline Kontrol & $2,90 \pm 0,7^{\mathrm{ab}}$ & $35,13 \pm 3,8^{\mathrm{c}}$ & $3,03 \pm 0,4^{\mathrm{c}}$ & $0,58 \pm 0,1^{\mathrm{a}}$ \\
SW 0.50\% & $2,83 \pm 0,5^{\mathrm{ab}}$ & $31,78 \pm 3,5^{\mathrm{bc}}$ & $2,57 \pm 0,1^{\mathrm{bc}}$ & $0,59 \pm 0,2^{\mathrm{a}}$ \\
Fungisida (B) & $4,36 \pm 0,6^{\mathrm{b}}$ & $38,02 \pm 4,5^{\mathrm{c}}$ & $4,33 \pm 0,7^{\mathrm{d}}$ & $1,29 \pm 0,2^{\mathrm{b}}$ \\
Bubur Bordo & $3,83 \pm 0,5^{\mathrm{ab}}$ & $21,00 \pm 2,4^{\mathrm{ab}}$ & $1,73 \pm 0,3^{\mathrm{ab}}$ & $0,56 \pm 0,1^{\mathrm{a}}$ \\
M+SW 0.50\% & $4,00 \pm 0,6^{\mathrm{ab}}$ & $19,28 \pm 2,8^{\mathrm{a}}$ & $0,71 \pm 0,1^{\mathrm{a}}$ & $0,26 \pm 0,0^{\mathrm{a}}$ \\
M 0.50\% & $3,07 \pm 0,5^{\mathrm{ab}}$ & $29,34 \pm 3,3^{\mathrm{abc}}$ & $1,23 \pm 0,3^{\mathrm{a}}$ & $0,38 \pm 0,1^{\mathrm{a}}$ \\
M+SW 0.25\% & $3,33 \pm 0,4^{\mathrm{ab}}$ & $29,06 \pm 3,7^{\mathrm{abc}}$ & $1,77 \pm 0,4^{\mathrm{ab}}$ & $0,64 \pm 0,0^{\mathrm{a}}$ \\
M+SW 0.75\% & $2,40 \pm 0,4^{\mathrm{ab}}$ & $27,42 \pm 3,4^{\mathrm{abc}}$ & $1,16 \pm 0,2^{\mathrm{a}}$ & $0,34 \pm 0,1^{\mathrm{a}}$ \\
\hline
\end{tabular}

Kecepatan munculnya gejala budokini didukung oleh metode infeksiyang tepat, konsentrasi, virulensi patogen, dan kondisi lingkungan yang sesuai. Selain itu, faktor ketahanan tanaman sendiri juga berperan dalam menentukan berapa lama waktu yang dibutuhkan kapang untuk menimbulkan gejala awal. Gejala awal budok ditandai dengan terbentuknya bintil (kutil) berwarna hijau kekuningan pada tunas atau cabang baru yang posisinya dekat dengan permukaan tanah menurut Karling (1964) kutil tersebut terbentuk karena pertambahan jumlah sel (hiperplasia) dan ukuran sel (hipertrofi) tanaman sebagai reaksi terhadap senyawa yang dikeluarkan oleh Synchytrium sp. selama infeksi.

Intensitas dan laju infeksi penyakit dipengaruhi oleh virulensi patogen, kondisi lingkungan, dan kerentanan tanaman inang. Tanaman muda lebih rentan terhadap serangan patogen (Agrios, 2005). Struktur jaringan tanaman yang lebih tua dan keras merupakan salah satu penyebab kutil muncul pada bagian pucuk tanaman (Wahyuno dan Sukamto, 2010). Perkembangan patogen Synchytrium pogostemonis dipengaruhi oleh kandungan air, sehingga pada musim hujan perkembangan penyakit relatif lebih cepat dibanding musim kemarau (Sumardiyono et al. 2008). Jumlah inokulum dan lamanya perendaman akar dapat mempengaruhi kecepatan munculnya gejala budok. Hasil 
penelitian Hidayah dan Yulianti (2010) jumlah inokulum berpengaruh nyata terhadap kejadian penyakit lanas yang disebabkan oleh Phytophthora nicotianae. Kejadian penyakit tertinggi yaitu 53,9-56,9\% tertinggi pada tanaman yang diinokulasi dengan 1.350-2.400 zoospora/bibit pada umur 5 minggu setelah semai (MSS). Pada penelitian ini inokulum S. pogostemonis yang digunakan untuk inokulasi adalah sekitar $119.600 \mathrm{spora} / \mathrm{ml}$ dan dapat menimbulkan gejala penyakit budok pada umur dua minggu pasca inokulasi.

Ketahanan tanaman terhadap serangan patogen merupakan suatu sifat yang memungkinkan tanaman memiliki daya tahan terhadap serangan tersebut. Menurut Hammerschmidt \& Dann (2000) ketahanan tanaman secara biokimiawi ditunjukkan ketika tanaman mampu menghasilkan senyawa kimia yang mampu mencegah pertumbuhan dan perkembangan patogen, senyawa tersebut dapat berupa PR protein (Pathogenesis-Related Proteins). Selain itu tanaman juga mampu menghasilkan metabolit sekunder berupa senyawa alkaloida, fenol, flavonida, glikosida, fitoaleksin, dan lain sebagainya (Chairul, 2003). Mekanisme tersebut tidak menghambat metabolisme dan pertumbuhan tanaman dan dapat meningkatkan produksi dan ketahanan tanaman terhadap stres lingkungan (Hammerschmidt \& Dann, 2000; Vallad \& Goodman, 2004; Desmawati, 2006).

Tabel 4. Pengaruh Perlakuan Minyak Atsiri dan Fungisida Kimia terhadap Synchytrium pogostemonis pada Persentase Keterjadian Penyakit pada Tanaman Nilam yang Ditanam pada Lahan Endemik Budok pada Umur 6 Bulan

\begin{tabular}{lllll}
\hline & \multicolumn{2}{l}{$\begin{array}{l}\text { Nilam yang bertahan } \\
\text { hidup }\end{array}$} & \multicolumn{2}{l}{ Nilam yang bertahan hidup } \\
\cline { 2 - 5 } Perlakuan & Jumlah & $\%$ & Jumlah & $\%$ \\
\hline Kontrol & 44 & 73,3 & 9 & 20,45 \\
F Benomil 0,3\% & 47 & 78,3 & 0 & 0,00 \\
Bubur Bordo 0,1\% & 43 & 71,6 & 2 & 4,65 \\
SW 0.50\% & 39 & 63 & 10 & 25,64 \\
M 0.50\% & 42 & 70 & 12 & 28,57 \\
M+SW 0.25\% & 39 & 63 & 9 & 23,08 \\
M+SW 0.50\% & 32 & 53,3 & 3 & 9,37 \\
M+SW 0.75\% & 38 & 63,3 & 4 & 10,53 \\
\hline
\end{tabular}

PERCOBAAN 2. EFEKTIVITAS MINYAK ATSIRI SEBAGAI PESTISIDA NABATI TERHADAP PENYAKIT BUDOK PADA TANAMAN NILAM

Minyak atsiri memiliki senyawa yang diketahui dapat menghambat pertumbuhan kapang patogen. Minyak atsiri tersebut berpotensi digunakan sebagai pestisida nabati untuk mengurangi ketergantungan terhadap fungisida kimia. Minyak atsiri tersebut juga memungkinkan digunakan untuk mengendalikan penyakit budok pada tanaman nilam.

Hasil percobaan pada tahapan ini menunjukkan bahwa perbedaan perlakuan yang diberikan tidak berpengaruh nyata terhadap pertumbuhan jumlah cabang nilam, namun memberika perbedaan yang nyata terhadap tinggi tanaman. Gejala budok pda umumnya muncul pada tunas-tunas yang baru terutama pada batang yang berdekatan dengan permukaan tanah. Menurut Wahyuno et al. (2007) tanaman yang terinfeksi penyakit budok akan mengalami pengerdilan, pada percobaan ini tanaman yang diberikan pestisida kimia menunjukkan pertumbuhan tinggi tanaman yang lebih besar Tinggi tanaman berkaitan dengan rendahnya aktivitas fotosintesis akibat tertutupnya permukaan daun oleh gejala penyakit budok (Tabel 3).

Pada percobaan ini pemberian perlakuan fungisida kimia benomil 0,3\% memiliki perbedaan yang nyata pada bobot basah dan bobot kering tanaman (Tabel 3). Hasil penelitian Sumardiyono et al. (2013) penyemprotan 
fungisida benomil $0.1 \%$ berpengarih pada bobot basah nilam yang tinggi. Besarnya bobot basah dan bobot kering tanaman dikarenakan tanaman tidak mengalami serangan penyakit sehingga pertumbuhan pun tetap normal. Pada saat tanaman mengalami stres ataupun sakit tanaman akan meminimalisir pertumbuhannya dan lebih memfokuskan pada sistem pertahanan tanaman. Menurut Idris dan Nasrun (2009) tanaman nilam yang terinfeksi penyakit budok dengan serangan berat terlihat adanya penyumbatan patogen pada pembuluh xylem yang cukup tinggi yaitu 46,50$59,00 \%$. Pada saat translokasi air terhambat maka proses fisiologis tanaman akan terganggu, sehingga pertumbuhan tanaman menjadi terhambat (Cullen et al.,2000). Tanaman yang tahan akan cepat merespon serangan patogen dengan membentuk sistem pertahanan seperti produksi tilosis, induksi barier non spesifik, dan adanya getah (gums) dan deposit-deposit yang lain sehingga dapat menahan penyebaran patogen didalam tubuh tanaman (Agrios, 2005).

Pada Tabel 4 persentase keterjadian penyakit $(\mathrm{KeP})$ berturut-turut dari yang terkecil yaitu fungisida benomil yaitu 0,00\%; bubur bordo sebesar 4,65\%; Mimba+Seraiwangi konsentrasi 0,50\% dengan persentase kejadian penyakit sebesar 9,37\%. Persentase kejadian penyakit dihitung ketika mulai muncul gejala penyakit budok berupa kutil berwarna merah keunguan yang muncul pada permukaan bawah daun, petiol, dan batang (Gambar 1). Pengendalian penyakit budok dengan fungisida kimia benomil 0,3\% memang masih menjadi pilihan utama karena dianggap lebih efektif dibandingkan dengan pestisida nabati. Hal ini sesuai dengan hasil penelitian Sukamto et al., (2014) tanaman nilam yang diberi perlakuan bubur bordo dan fungisida berbahan aktif benomil tidak menunjukkan gejala penyakit budok di lapangan. Hasil penelitian Kusnanta (2005) juga menyatakan benomil lebih efektif menekan pertumbuhan penyakit budok.

Penggunaan fungisida kimia dengan konsentrasi yang tepat dan penggunaan dosis yang sesuai dengan dosis pada kemasan fungisida tidak dapat menghambat pertumbuhan tanaman nilam (Tabel 3). Namun penggunaan fungisida kimia skala besar dapat mengakibatkan dampak negatif karena bersifat polutan, tidak dapat terdegradasi, dan toksisitas residu yang tidak terurai. Bahan kimia sintesis diketahui memiliki sifat karsinogenik, teratogenik, onkogenik dan genotoksik. Patogen tanaman berangsur-angsur menjadi tahan terhadap fungisida kimia (Prasad, et al., 2010). Menurut Sumardiyono (2008) penggunaan fungisida sistemik termasuk benomil secara terus-menerus akan menimbulkan kapang patogen tahan terhadap fungisida.

Hasil penelitian ini pestisida nabati formula campuran minyak atsiri Mimba dan Seraiwangi pada konsentrasi 0,50\% dapat menjadi alternatif untuk menghambat pertumbuhan penyakit budok. Pemberian formula campuran ini menunjukkan gejala penyakit sebesar 9,37\%. Namun menunjukkan parameter pertumbuhan yang sangat rendah seperti pertambahan tinggi $19,28 \mathrm{~cm}$, bobot basah 0,71 gram dan bobot kering 0,26 gram (Tabel 3). Alternatif lain yang memiliki persentase keterjadian penyakit budok yang rendah yaitu 10,53\% dan memiliki parameter pertumbuhan yang cukup baik yaitu formula campuran minyak atsiri Mimba dan Seraiwangi 0,75\% (Tabel 4).

Minyak atsiri yang dihasilkan dari mimba maupun seraiwangi mengandung banyak bahan aktif dengan jumlah dan fungsi yang berbeda. Hal tersebut menjadikan minyak atsiri lebih efektif dibandingkan dengan senyawa bahan aktif tunggal dalam menghambat patogen. Formula campuran minyak atsiri mimba dan seraiwangi memiliki lebih banyak mengandung senyawa aktif, sehingga dapat mencegah resistensi dari patogen tanaman. Hasil penelitian menunjukkan bahwa pestisida nabati dapat menekan kejadian penyakit budok, namun belum maksimal dan masih menunjukkan gejala di lapangan. Pestisida nabati terdiri dari bahan alami yang bersifat mudah terurai (biodegradable) sehingga tidak mencemari lingkungan dan residunya mudah hilang. Penggunaan pestisida nabati dapat menjadi salah satu alternatif yang bertujuan agar tidak tergantung kepada pestisida sintesis (Kardinan, 2002).

Minyak atsiri merupakan senyawa hasil metabolit sekunder yang bermanfaat untuk pertumbuhan dan 
pertahanan tanaman. Sitronelal dan geraniol merupakan komponen utama minyak serai wangi (Guenther, 1994). Kandungan bahan aktif lain pada minyak atsiri seraiwangi selain sitronelal adalah monterpen, nerol, limonen, linalool, $\beta$-caryphyllene, dan myrcen. Bahan-bahan aktif tersebut mengandung senyawa terpene yang merupakan komponen dominan dan efektif sebagai antifungi (Sirirat et al., 2009; Vanitha, 2010). Senyawa tersebut memiliki sifat bakterisidal terhadap beberapa jenis bakteri dan sifat antifungal (Sait, 1991). Hasil penelitian Prasad et al. (2010) menyatakan bahwa sitronelal dapat menghambat pertumbuhan miselium kapang Phomopsis azadirachtae pada konsentrasi 1500 ppm. Hasil pengujian Chrisnawati (2004) mengindikasikan bahwa formula sitronelal dapat menghambat pertumbuhan jamur Fussarium oxysporum f.sp. lycopersici secara in vitro. Nasrun et al. (2005) juga melaporkan komponen sitronelal dan geraniol dapat menghambat pertumbuhan Ralstonia solanacearum penyebab penyakit layu bakteri nilam secara in vitro. Yulia (2006) melaporkan bahwa minyak seraiwangi menunjukkan penghambatan yang kuat terhadap perkecambahan spora pada beberapa patogen. Pada penelitian Tzortzakis dan Economakis (2007) melaporkan bahwa minyak seraiwangi pada konsentrasi 0,5\% dapat menghambat pertumbuhan spora hingga $100 \%$.

Senyawa sitronelal termasuk dalam kelompok terpenoid yang mampu menekan pertumbuhan jamur patogen. Senyawa aktif ini dapat menghambat proses metabolisme jamur sehingga mengganggu pertumbuhannya (Knobloch et al., 1989). Menurut Li et al. (2013) pemberian sitronelal konsentrasi 0,5 dan 2\% pada hifa Aspergillus niger dengan masa inkubasi 24 jam dapa menyebabkan perubahan struktur morfologi pada hifa yaitu menjadi berkerut, menggulung dan hancur karena kehilangan sitoplasma, serta terjadi kerusakan pada membran plasma sel dan organel sel seperti mitokondria dan vakuola kapang. Minyak atsiri mimba memiliki bahan aktif azadirachtin. Menurut Massini et al. (2009) azadirachtin banyak terdapat pada biji mimba yang matang. Hegde et al. (2014) menyatakan bahwa azadirachtin pada konsentrasi 5\% dapat menghambat pertumbuhan miselium Colletotrichum gloeosporioides hingga 89,99\% pada tanaman jarak pagar (Jatropha curcas). Minyak atsiri mimba pada konsentrasi 5\% juga bersifat toksik yang dapat menghambat miselium Macrophomina phaseolina penyebab charcoal rot pada banyak jenis tanaman hingga 95,5\% (Dubey et al., 2009).

\section{KESIMPULAN DAN SARAN}

\section{KESIMPULAN}

Pada penelitian ini didapatkan bahwa Nilam varietas Patchoulina 1 lebih rentan terhadap infeksi Synchytrium pogostemonis penyebab penyakit budok dibandingkan dengan varietas Patchoulina 2 dan Sidikalang. Minyak atsiri formula campuran mimba dan seraiwangi konsentrasi 0,50\% dapat digunakan sebagai alternatif fungisida kimia untuk menekan kejadian penyakit budok pada tanaman nilam walaupum efektivitasnya lebih rendah dibandingkan fungisida kimia benomil dan bubur bordo, serta penggunaan pestisida nabati tidak menghambat pertumbuhan nilam.

\section{DAFTAR PUSTAKA}

Agrios, G.N. 2005. Plant Pathology, 5th ed. Elsevier Academic Press, California.

Agusta A. 2000. Minyak Atsiri Tumbuhan Tropika Indonesia. Bandung : ITB Press.

Agustian E, Sulaswaty A, Laksmono J.A, Adilina I.B. 2007. Pemisahan sironelal dari minyak sereh wangi menggunakan 
unit fraksionasi skala bench. J. Tek. Ind. Pert. 17 (2): 49-53.

Guenther, E. 1994. Minyak Atsiri. Jilid IVA. Universitas Indonesia Press, Jakarta. 407 hlm.

Hammerschimdt, R., E.K. Dann. 2000. Induced resistance to disease. environmentally safe approach to crop disease control. Chapter 8. Lewish Publishers, Boca Raton. pp. 177-194.

Hartati S.Y, Sukamto, N. Karyani, dan Zulhisnain. 2014. Efektivitas Formula Minyak Cengkeh, Eukaliptus, Mimba, dan Seraiwangi terhadap Penyakit Budok pada Tanaman Nilam. Badan Penelitian dan Pengembangan Pertanian. Balittro. Bogor. [Unpublish data].

Idris H dan Nasrun. 2009. Pengaruh Cara Inokulasi Synchytrium Pogostemonis Terhadap Gejala Budok dan Pertumbuhan Nilam. Balai Penelitian Tanaman Obat dan Aromatik KP. Laing Solok, Sumatera Barat.

Kardinan, A. 2000. Pestisida Nabati, Ramuan dan Aplikasi. Jakarta: Penerbit Penebar Swadaya.

Karling J. 1964. Synchytrium. NewYork: Academic Press.

Knobloch, K.A., B. Paul., H. Ilber, Weigand, W. Weil. 1989. Antibacterial and antifungal properties of essential oil components. J. Ess. Oil. $1: 119128$.

Laba I.W, M. Willis, Rohimatun, Ahyar, N. Tarigan, C. Sukmana. 2011. Pengendalian hama penggerek buah (Conopomorpha cramerella) $>50 \%$ dan penyakit busuk buah (Phytopthora palmivora) $>30 \%$ pada tanaman kakao. Laporan Tahunan. Balai Penelitian Tanaman Rempah dan Obat.

Li W, Qing-Shan, You-Sheng, Yi-Ben, Shun-Shan. 2013. Antifungal effect of cittronella oil against Aspergillus niger ATCC 16404. Appl Microbiol Biotechnol 97: 7483-7492.

Nasrun, Christanti, T. Arwiyanto, dan I. Mariska. 2005. Pengendalian penyakit layu bakteri nilam menggunakan Pseudomonas fluorescens. Jurnal Penelitian Tanaman Industri 11(1): 19-24.

Nuryani Y. 2006. Budidaya Tanaman Nilam (Pogostemon cablin Benth.). Badan Penelitian dan Pengembangan Pertanian. Balittro.

Pelczar MJ Jr, Chan ECS. 1986. Dasar-dasar Mikrobiologi. Volume ke-1, 2. Hadioetomo RS, Imas T, Tjitrosomo SS, Angka SL, penerjemah; Jakarta: UI Press. Terjemahan dari: Element of Microbiology.

Sumardiyono C. 2008. Ketahanan jamur terhadap fungisida di Indonesia. J Perl Tan Indones. 14(1):1-5.

Sukamto, Syakir M, Djazuli M, Sukamto, Syakir M. dan Djazuli M. 2014. Pengendalian Penyakit Budok pada Tanaman Nilam dengan Agensia Hayati dan Pembenah Tanah. Balai Penelitian Tanaman Rempah dan Obat. Bogor.

Wahyuno D. 2010. Pengelolaan Perbenihan Nilam untuk Mencegah Penyebaran Penyakit Budok (Synchytrium pogostemonis). Ind. Medic. Arom Crops Res. Institute. Balitro. 16(1):01-11.

Wahyuno D, S.Y. Hartati, S.R. Djiwanti, R. Noveriza, dan Sukamto. 2011. Penyakit penting pada tanaman nilam dan usaha pengendaliannya. Bunga Rampai Nilam. Badan Litbang Pertanian, Puslitbangbun, Balai Penelitian Tanaman Rempah dan Obat. Hlm. 66-110. 